\title{
O PODER NORMATIVO DAS AGÊNCIAS REGULADORAS: DEMOCRACIA E DIREITOS FUNDAMENTAIS
}

\author{
Rafael Rott de Campos Velho ${ }^{1}$
}

\begin{abstract}
RESUMO: O escopo do presente trabalho é demonstrar o quanto os regulamentos expedidos por agências reguladoras independentes são importantes no cenário hodierno para a garantia da Democracia e dos Direitos Fundamentais. Tais autoridades precisam ser dotadas de relativa independência, haja vista os interesses da sociedade em jogo no processo de tomada de certas decisões técnicas, as quais podem afetar qualquer cidadão. No entanto, o campo de atuação dos entes em questão deve sofrer limitações com o intuito de garantir a legitimação popular.
\end{abstract}

PALAVRAS-CHAVE: Normas. Agências Reguladoras. Democracia. Direitos Fundamentais.

\section{THE NORMATIVE POWER OF THE INDEPENDENT REGULATORY AGENCIES: DEMOCRACY AND BASIC RIGHTS}

ABSTRACT: The objective of this work is to demonstrate the importance of the Independent Regulatory Agencies' regulations in the current situation for the guarantee of Democracy and Basic Rights. It's necessary that the referred authorities have relative independency because there are a large number of society's interests when a technical decision, which can affect each citizen, is taken. Nonetheless, the sphere of action of these authorities has to be limited, protecting the popular legitimacy.

KEY-WORD: Regulations. Independent Regulatory Agencies. Democracy. Basic Rights.

\section{INTRODUÇÃO}

O Estado Democrático de Direito toma uma nova roupagem no cenário hodierno. Nesse sentido, essa nova forma de Estado difere da clássica, na qual o seu papel era apenas o de garantidor dos direitos individuais e das liberdades aos cidadãos. Essa concepção, típica da era do iluminismo e da Revolução Francesa vinha a ser o contraponto aos regimes autoritários vigentes na Europa no período anterior ${ }^{2}$. Dessa forma, esse modelo de ente estatal comportava amplos mecanismos destinados a preservar a defesa do cidadão frente ao Estado opressor.

O Estado moderno, sem deixar de realizar o referido papel, passa a ter outras funções ancilares. Cumpre aqui fazer uma rápida referência a John Rawls. Um dos grandes expoentes contemporâneos da filosofia política, opoente do Utilitarismo

\footnotetext{
1 Acadêmico do Curso de Direito da Universidade Federal de Santa Maria (UFSM). E-mail: rafael.campos.velho@gmail.com.

${ }^{2} \mathrm{O}$ exemplo mais elucidativo é o ancien régime, prática absolutista vigente na França antes da Revolução.
} 
Clássico de Jeremy Bentham e John Stuart Mill ${ }^{3}$, Ralws preconiza pela existência de uma sociedade fundada em dois princípios basilares ${ }^{4}$, quais sejam o da igualdade e o da diferença:

Primeiro: cada pessoa deve ter um direito igual ao sistema mais extenso de iguais liberdades fundamentais que seja compativel com um sistema similar de liberdades para as outras pessoas.

Segundo: as desigualdades sociais e econômicas devem estar dispostas de tal modo que tanto (a) se possa razoavelmente esperar que se estabeleçam em benefício de todos como (b) estejam vinculadas a cargos e posições acessíveis a todos 5 . (RAWLS, 2008, p. 73).

Dessa forma, ao defender que as desigualdades econômicas só devem existir dentro de um cenário no qual prevaleça a igualdade de oportunidades e que elas não podem constituir nenhum caráter nocivo à sociedade (pelo contrário, as desigualdades devem ser benéficas para a coletividade), Ralws está admitindo a imprescindibilidade da intervenção estatal na economia.

Nesse sentido, escreveu Joaquim B. Barbosa Gomes (2006), ministro do Supremo Tribunal Federal (STF):

(...) de um Estado absteísta e mero garantidor da ordem e do cumprimento dos contratos, expressão máxima do direito de propriedade, o mundo assistiu à emergência de um Estado intervencionista, provedor de prestações tendentes a minimizar e a corrigir as imperfeições e iniquidades do sistema capitalista(...) $E$, pois, nesse contexto de irreprimível necessidade de intensificação da presença corretiva do Estado no jogo capitalista que nasce a ideia de regulação como indeclinável função governamental, pelo menos naquele que é visto como seu berço histórico, isto é, os Estados Unidos da Américá. (BARBOSA GOMES, 2006, p. 21).

\footnotetext{
${ }^{3}$ Para o próprio Ralws (2008, p. 26-41), a característica fulcral do Utilitarismo Clássico era o fato de a medida do grau de satisfação de uma sociedade ser revelada pela média de satisfação individual de cada um de seus membros. Dessa forma, o filósofo em tela busca por uma alternativa a essa doutrina que dominou a filosofia política anglo-saxã durante o século XIX e boa parte do XX.

${ }^{4}$ Importante ressaltar que o método para se chegar aos princípios norteadores da estrutura básica da sociedade são uma regressão a uma "Posição Original", na qual os indivíduos tomados pelo "véu da ignorância" (sem ter convicções políticas, religiosas, morais, opiniões formadas, enfim indivíduos desprovidos de qualquer informações, mas dotados de racionalidade), optariam, por diversas razões expostas pelo autor, pelos dois princípios de justiças apresentado na obra. (RAWLS, 2008, p. 144-226).

${ }^{5}$ Rawls (2008) desenvolve tais princípios no decorrer de sua obra aperfeiçoando-os, o que conduz a uma redação mais elaborada, profícua e precisa. No entanto, para o presente trabalho, optou-se pela primeira definição, introduzida logo no introito do livro, haja vista a necessidade de se aprofundar demasiadamente em conceitos para tornar possível o pleno entendimento da última definição apresentada. Outrossim, a exposição dessa teoria é meramente explicativa e não constitui ponto central no artigo.

${ }^{6}$ Como será exposto alhures, foi nos Estados Unidos que surge o Direito Regulatório e, por conseguinte, as Agências Regulatórias Independentes (Independent Regulatory Agencies).
} 
Nessa ordem de ideias, torna-se interessante expor, de maneira singela, aquilo que Fábio Nusdeo (2005, p. 141-167) chama de "falhas do mercado". Assim, elementos como rigidez dos fatores, ou seja, baixa mudança do quadro social, atrelada a dificuldade de mudanças dinâmicas no quadro econômico ${ }^{7}$, falta de acesso a informações relevantes, concentração econômica, entre outros constituem falhas do sistema capitalista e representam a necessidade de o Estado atuar corrigindo-as.

Eros Roberto Grau ([SD] apud NUSDEO, 2005, p. 198-199) distingue quatro modalidades de intervenção do Estado na economia. Primeiramente, pode o governo interferir na economia pela (a) direção, consistente na elaboração de normas cogentes destinadas aos agentes econômicos, $v$. $g$., fixação de preços, definição de quotas de exportação, entre outras. De outro modo, pode o poder público atuar mediante (b) absorção ou (c) participação, modalidades nas quais o Estado traz para si a responsabilidade por alguns setores da economia, absorvendo um campo econômico (monopólio estatal) ou participando dele mediante a atuação de agentes econômicos públicos (empresas estatais), os quais concorrem com os entes privados. Por fim, pode intervir na economia por meio da (d) indução, isto é, utilizando-se de mecanismos institucionais que permitem uma condução da economia sem interferência direita, $v . g$, fixação de taxa de juros, aumento ou diminuição da tributação sobre determinado setor.

Luís Roberto Barroso (2006, p. 65), por seu turno apresenta outra classificação, semelhante à exposta, para a intervenção estatal na economia. Coloca três principais formas de atuação: (a) poder de polícia, editando normas cogentes que indicam o caminho da economia (Código de Defesa do Consumidor, Lei de Remessa de Lucros, Lei de Repressão ao Abuso do Poder Econômico, entre outras), ou atuando na fiscalização trabalhista e sanitária, por exemplo; (b) fomento, isto é, mediante a disponibilização de financiamentos a baixo custo, desoneração tributária de determinado setor, oferecimento de subsídios, etc. (assemelha-se a prática descrita por indução); e (c) prestando serviços públicos ou explorando atividades econômicas, ou seja, participando diretamente de um ramo da economia.

Até aqui se procurou traçar um panorama didático acerca da interferência do Estado na economia, buscando, de forma sintética, demonstrar o quanto isto é

\footnotetext{
${ }^{7}$ Nem sempre as leis da economia (como oferta e procura) têm aplicação. O exemplo de Fábio Nusdeo (2005, p. 144): se o preço do feijão subir, os brasileiros permanecerão comprando o produto devido aos seus hábitos calcados em fatores culturais.
} 
impositivo no cenário hodierno. Agora, de forma igualmente singela, procurar-se-á demonstrar como essa temática tomou corpo no contexto brasileiro.

Para Luís Roberto Barroso (2005, p. 60-62), o Brasil nunca foi um Estado propriamente liberal aos moldes dos construídos na era do iluminismo. A presença estatal sempre foi constante na vida econômica do país. Como cita o referido autor, "as bênçãos do poder estatal sempre foram - ressalvadas as exceções que confirmam a regra - a razão do êxito ou do fracasso de qualquer projeto político, social ou empresarial" (BARROSO, 2006, p. 60).

Desse modo, nas mais variadas eras que se viveu na história brasileira, a mão do Estado sempre teve papel central. Seja durante o império, período no qual os cafeicultores eram subsidiados pelo governo, o que persistiu durante a República Velha (1889-1930), seja na era Vargas, onde o estatalismo foi acentuado, seja no Regime Militar onde foram criadas dezenas de estatais (Eletrobrás, Nuclebrás, Siderbrás, etc.), o Estado nunca abdicou da sua função de norteador da sociedade.

Tais circunstâncias acabaram gerando um Estado inflado, burocratizado e inoperante, que acumulava funções de todas as naturezas, buscando o controle de diversos setores da economia, sem, no entanto, favorecer a coletividade (como qualquer leigo pressuporia), mas que dotava os amigos da corte de um poder que ameaçava perpetuar a ordem social vigente.

Nesse sentido, somente na década de 1990 é que aparecem os albores das reformas (embora superficiais), nas quais começaram a ser transferidos à iniciativa privada alguns setores da economia ${ }^{8}$.

Com efeito, o Estado brasileiro, com o incremento da iniciativa privada, sentiu a necessidade de, a exemplo dos Estados Unidos, criar as chamadas Agências Regulatórias Independentes, para assegurar o "poder de intervenção nos mais diversos setores em que se faz necessária a presença reguladora e disciplinadora do Estado" (BARBOSA GOMES, 2005, p. 30-1). Vale ressaltar que as agências reguladoras não atuam apenas sobre setores econômicos, mas também em campos de monopólio estatal

\footnotetext{
${ }^{8}$ Cumpre, nesse momento, enfatizar de pronto, que o objeto desse artigo não é julgar corretas as práticas de privatizações que foram conduzidas no Brasil na década de 1990. Pelo contrário, simplesmente está se constatando que o Estado inflado formado ao longo de dois séculos não foi capaz de reduzir as desigualdades sociais, pelo contrário, contribuiu veementemente para a concentração de renda. Destarte, o estatalismo brasileiro só favoreceu a alguns, os quais se beneficiaram do Estado ditador das regras para concentrar dinheiro e poder. Assim, entende-se que o Estado não deve ser fomentador da concentração econômica, mas pelo contrário, impulsionador da concorrência. Vale destacar que os conservadores brasileiros (que sempre se declararam liberais), desfrutaram desse Estado condutor da economia para aquinhoar poder e renda.
} 
(regulando serviços públicos, v. g. a Agência Estadual de Regulação dos Serviços Delegados no Rio Grande do Sul - AGERGS) ou ainda, na defesa de direitos difusos, como a Agência Nacional das Águas (ANA).

Nesse sentido, tais agências gozam de uma autonomia reforçada, consubstanciada, mormente, nos mandatos fixos dos dirigentes (que não se submetem aos arbítrios do governo), na independência orçamentária e administrativa e na faculdade de emitir normas cogentes em seu campo de atuação (BARROSO, 2006, p. 70-74).

Nesse passo, Gustavo Binenbojm (2008, p. 267) assevera que elas caracterizam uma administração pública policêntrica ${ }^{9}$, haja vista a independência assegurada a tais agências. Dessa forma, essa maneira de governar assegura maior tecnicidade para a tomada de decisões no âmbito de regulação de alguns setores específicos, sem, contudo, esvaziá-los de política, intrínseca à administração pública.

O presente artigo terá três pontos cruciais: o primeiro traçará um panorama genérico e histórico sobre as agências reguladoras. O segundo tem por escopo trazer a discussão acerca da natureza jurídica das normas expedidas por tais entes públicos. Finalmente, o terceiro procurará demonstrar meios pelos quais as normas expedidas pelas autoridades administrativas independentes podem estar em consonância com os ditames das linhas governamentais (haja vista sua legitimação popular) e pela própria sociedade, de maneira direta.

Essa trilha descrita tem como objeto demonstrar o quanto as agências reguladoras são importantes para o Estado de Direito, mas, igualmente, o quanto faz-se necessária a imposição de limites a suas atuações, a fim de preservar a Democracia e os Direitos Fundamentais.

\section{BREVE HISTÓRICO, CONSTITUCIONALIDADE E PECULIARIDADES DAS AGÊNCIAS REGULADORAS}

\footnotetext{
${ }^{9}$ Gustavo Binenbojm, no último capítulo de sua obra "Uma teoria do Direito Administrativo: Direitos Fundamentais, Democracia e Constitucionalização", intitulado "Do executivo unitário à administração pública policêntrica", assevera que a emergência de autoridades administrativas independentes (como as agências reguladoras), dão as bases para que a administração pública deixe de ser centralizada apenas na autoridade máxima do executivo, haja vista o caráter de independência que são dotadas essas autoridades. Por tal razão, o referido autor utiliza o termo "administração pública policêntrica".
} 
As agências reguladores surgiram nos Estados Unidos, no final do século XIX, precisamente "em 1887, com a criação da Interstate Commerce Comission "10, instituída para a regulação dos serviços interestaduais de transporte ferroviário e tida como a primeira agência reguladora independente norte-americana” (BINENBOJM, 2008, p. 247).

Entretanto, as agências reguladoras ganharam destaque na era pós new deal. Conhecidas como Independent Regulatory Agencies, elas passaram a ser consideradas uma nova expressão da administração pública, haja vista seu caráter de independência do poder executivo central. Dessa forma, foram impulsionadas pela política do presidente Roosevelt, que pregava maior interferência do poder estatal na economia (tendo em vista a crise do liberalismo que abalou o mundo em 1929). Portanto, no cenário estadunidense, as agências reguladoras nascem em um cenário no qual se buscava uma maior interferência do Estado no âmbito econômico (MENDES [SD] apud BARBOSA GOMES, 2005, p. 29-30).

Desse modo, cumpre salientar que no Brasil, no período de surgimento das agências reguladoras, vivia-se um cenário frontalmente oposto ao dos Estado Unidos. Buscava-se impulsionar uma política chamada neoliberal, garantindo maior autonomia ao mercado. Assim, as agências reguladoras surgiram ao lado das privatizações da década de 1990, sendo uma das bandeiras do governo Fernando Henrique Cardoso (BINENBOJM, 2008, p. 272-273).

Nesse sentido, cumpre transcrever, novamente, as palavras de Gustavo Binenbojm (2008):

A atração do setor privado, notadamente o capital internacional, para o investimento nas atividades econômicas de interesse coletivo e serviços públicos objeto do programa de privatizações e desestatização estava condicionada à garantia de estabilidade e previsibilidade das regras do jogo nas relações dos investidores com o Poder Público.

$\mathrm{Na}$ verdade, mais do que um requisito, o chamado compromisso regulatório (regulatory commitment) era, na prática, verdadeira exigência do mercado para a captação de recursos. (BINENBOJM, 2008, p. 272).

\footnotetext{
${ }^{10}$ Como bem destaca Conrado Hübner Mendes ([SD] apud BARBOSA GOMES, 2005, p. 29): “o nascimento desse modelo de regulação deu-se em 1887, quando se verificou a premente necessidade de se conferir uma resposta reguladora às disputas que estavam a ocorrer entre as empresas de transportes ferroviários e os empresários rurais". Nesse momento surgiu a Interstate Commerce Comission com o intuito de regular o comércio ferroviário interestadual. Dessa forma, resta claro que o primeiro clamor pela existência de uma autoridade reguladora independente deu-se exatamente devido a um conflito de interesses econômicos (in casu, entre agricultores e transportadores), o que despertou a necessidade de intervenção estatal para acalmar os ânimos e evitar maior prejuízo à economia.
} 
Tal conjuntura, observada no decorrer do processo de surgimento das agências reguladoras no Brasil, tem esse caráter peculiar devido aquilo que foi referido no introito desse trabalho, isto é, ao estatalismo exacerbado e concentrador que predominou no país desde o império até o ocaso do período ditatorial.

Delimitado o cenário de nascimento das agências reguladoras no Brasil, cumpre destacar, rapidamente, as discussões constitucionais atinentes à matéria.

Nos Estados Unidos, a constitucionalidade das agências reguladoras foi objeto de análise da Suprema Corte. Nas palavras de Joaquim B. Barbosa Gomes (2005):

São múltiplos os debates constitucionais suscitados pela disseminação de agências reguladoras independentes e pelas mudanças radicais na forma de organização do Estado que elas provocam. Esses debates abordam desde os riscos institucionais que elas representam em face da sua carência de legitimação democrática, passam pela questão da separação de poderes $e$ desembocam na discussão acerca da intangiblidade do Poder incumbido da Prestação jurisdicional. (BARBOSA GOMES, 2005, p. 40).

A Suprema Corte estadunidense acabou por se posicionar favoravelmente às agências reguladoras, declarando sua constitucionalidade em diversos casos que lhe foram submetidos. Consoante Joaquim B. Barbosa Gomes (2005, p. 41-49), as declarações de constitucionalidade das normas atinentes às agências reguladoras, notadamente frente às arguições de que elas afetariam a divisão tripartite do poder, foram tomadas eivadas de pragmatismo e casuísmo. Ocorria a necessidade de se legitimar as decisões tomadas no cenário do New Deal, entre elas as criações das Independent Regulatory Agencies. Desse modo, a Suprema Corte acabou declarando a constitucionalidade dessas autoridades independentes ${ }^{11}$.

No Brasil, o paradigma case mais evidente acerca das agências reguladoras se refere à Agência Estadual de Regulação dos Serviços Delegados do Rio Grande do Sul (AGERGS). Cuida-se da Ação Direta de Inconstitucionalidade - ADI nº 1.949/RS. Ao apreciar a medida cautelar interposta na referida ação, o STF suspendeu o dispositivo legal que vedava a possibilidade de demissão de conselheiros, sem aprovação da assembleia legislativa do estado. Vislumbrou-se, in casu, ofensa ao princípio da

\footnotetext{
${ }^{11}$ Para um estudo mais profícuo da atuação da Suprema Corte Estadunidense nas questões envolvendo a constitucionalidade das agências reguladoras, ver Joaquim B. Barbosa Gomes: Agências Reguladoras: A "Metamorfose" do Estado e da Democracia (Uma Reflexão de Direito Constitucional Comparado), in Agências Reguladoras e Democracia, Gustavo Binenbojm (org), Rio de Janeiro: Lumen Juris, 2005.
} 
separação dos poderes. Entretanto, a decisão foi clara ao não impugnar as restrições legais a demissões dos conselheiros, sem motivação ${ }^{12}$.

Vale frisar, a guisa do que aponta Gustavo Binenbojm (2008, p. 259) que tal entendimento do Supremo foi oposto a uma decisão exarada em 1962 nos autos do Mandado de Segurança 8.693/DF, o qual resultou no verbete da súmula 25 do STF, in verbis: "a nomeação a termo não impede a livre demissão pelo Presidente da República, de ocupante de cargo dirigente de autarquia”. Dessa forma, ao julgar a ADI 1.949/RS, o Supremo reviu seu posicionamento à luz da Carta Magna de 1988, revertendo a jurisprudência anterior ${ }^{13}$.

As Propostas de Emendas Constitucionais (PECs) nº 81/2003 e 71/2007 visam a conferir caráter constitucional aos mandados fixos dos dirigentes de Agências Reguladoras, o que acabaria com a celeuma acerca de sua inconstitucionalidade (embora o STF aponte para a declaração da compatibilidade constitucional desses preceitos).

\footnotetext{
${ }^{12}$ Eis a ementa: I. Agências reguladoras de serviços públicos: natureza autárquica, quando suas funções não sejam confiadas por lei a entidade personalizada e não, à própria administração direta. II. Separação e independência dos Poderes: submissão à Assembléia Legislativa, por lei estadual, da escolha e da destituição, no curso do mandato, dos membros do Conselho Superior da Agência Estadual de Regulação dos Serviços Públicos Delegados do Rio Grande do Sul - AGERGS: parâmetros federais impostos ao Estado-membro. 1. Diversamente dos textos constitucionais anteriores, na Constituição de 1988 - à vista da cláusula final de abertura do art. 52, III -, são válidas as normas legais, federais ou locais, que subordinam a nomeação dos dirigentes de autarquias ou fundações públicas à prévia aprovação do Senado Federal ou da Assembléia Legislativa: jurisprudência consolidada do Supremo Tribunal. 2. Carece, pois, de plausibilidade a argüição de inconstitucionalidade no caso, do condicionamento à aprovação prévia da Assembléia Legislativa da investidura dos conselheiros da agência reguladora questionada. 3. Diversamente, é inquestionável a relevância da alegação de incompatibilidade com o princípio fundamental da separação e independência dos poderes, sob o regime presidencialista, do art. $8^{\circ}$ das leis locais, que outorga à Assembléia Legislativa o poder de destituição dos conselheiros da agência reguladora autárquica, antes do final do período da sua nomeação a termo. 4. A investidura a termo - não impugnada e plenamente compatível com a natureza das funções das agências reguladoras - é, porém, incompatível com a demissão ad nutum pelo Poder Executivo: por isso, para conciliá-la com a suspensão cautelar da única forma de demissão prevista na lei - ou seja, a destituição por decisão da Assembléia Legislativa -, impõe-se explicitar que se suspende a eficácia do $\operatorname{art.~} \mathbf{8}^{\circ}$ dos diplomas estaduais referidos, sem prejuízo das restrições à demissibilidade dos conselheiros da agência sem justo motivo, pelo Governador do Estado, ou da superveniência de diferente legislação válida. III. Ação direta de inconstitucionalidade: eficácia da suspensão cautelar da norma argüida de inconstitucional, que alcança, no caso, o dispositivo da lei primitiva, substancialmente idêntico. IV. Ação direta de inconstitucionalidade e impossibilidade jurídica do pedido: não se declara a inconstitucionalidade parcial quando haja inversão clara do sentido da lei, dado que não é permitido ao Poder Judiciário agir como legislador positivo: hipótese excepcional, contudo, em que se faculta a emenda da inicial para ampliar o objeto do pedido. (Grifou-se).

(ADI 1949 MC, Relator(a): Min. SEPÚLVEDA PERTENCE, Tribunal Pleno, julgado em 18/11/1999, disponível em <www.stf.jus.br>, acesso em 13/06/2009).

${ }^{13}$ O Min. Nelson Jobim utilizou-se do voto divergente do Min. Vitor Nunes Leal, vencido em 1962, para fundamentar seu voto.
} 
Dessa forma, no Brasil a tendência é de admissão da consonância das agências regulatórias com a ordem constitucional vigente.

Gustavo Binenbojm (2008, p. 256) pontua quatro características basilares das agências reguladoras: (a) independência política dos dirigentes, tendo em vista que são nomeados a termo, não podendo ser demitidos sem justificativas pelas autoridades do poder executivo; (b) independência técnica decisional, ou seja, prevalência de critérios técnicos nos processos de tomada de decisões; (c) independência normativa: faculdade de dispor sobre determinadas matérias por atos normativos próprios ${ }^{14}$; e (d) independência gerencial, orçamentária e financeira ampliadas.

No Brasil existem, atualmente, as seguintes agências reguladoras: Agência Nacional de Energia Elétrica - ANEEL - (Lei 9.427/97), Agência Nacional de Telecomunicações - ANATEL - (Lei 9.472/97), Agência Nacional do Petróleo - ANP (Lei 9.478/97), Agência Nacional de Saúde - ANS - (Lei 9.961/00), Agência Nacional das Águas - ANA - (Lei 9.984/00), Agência Nacional de Vigilância Sanitária ANVISA - (Lei 9.782/99), Agência Nacional de Transportes Terrestres - ANTT - (Lei 10.233/01, Agência Nacional de Transportes Aquáticos - ANTAQ - (Lei 10.233/01), Agência Nacional de Cinema - ANCINE - (Medida Provisória n²228-1/01) e Agência Nacional da Aviação Civil - ANAC - (Lei 11.182/05) ${ }^{15}$.

\section{A NATUREZA DAS NORMAS EXPEDIDAS PELAS AGÊNCIAS REGULADORAS}

Esclarecidas as circunstâncias de criação das agências reguladoras, bem como delimitado seus papeis no Estado moderno, torna-se imperiosa a análise da natureza das normas por elas editadas, como acima já se ressaltou, para que se verifique, mediante a ótica legalista e paradigmática, se há adequação das normas aos fins a que se propõem tais autarquias especiais.

Tem-se, na doutrina pátria, a adoção de três correntes para explicar o caráter das normas exaradas pelas agências reguladoras. São elas: natureza de atividade regulatória (patamar de Lei, compreendendo a tese da deslegalização), natureza de regulamento e

\footnotetext{
${ }^{14}$ Tal matéria será aprofundada a seguir.

15 Luís Roberto Barroso (2005, p. 69) coloca a Comissão de Valores Mobiliários como Agência Reguladora, haja vista suas características de independência, notadamente após a reforma legislativa consubstanciada na Lei 10.411/02, a qual lhe conferiu maior grau de autonomia.
} 
natureza de ato normativo-administrativo (normas de escalão inferior inclusive aos regulamentos do executivo).

\subsection{A tese da deslegalização}

A primeira tese que se apresenta é a chamada deslegalização, para a qual, a normativa das agências reguladoras tem o mesmo potencial de uma lei ordinária, podendo inclusive revogá-las.

Segundo o entendimento de Gustavo Binenbojm (2008), tal tese teve assento na doutrina estrangeira, a qual foi trazida ao Brasil por alguns doutrinadores. Dessa forma, o referido autor pontua que, sobretudo na Espanha e na Itália, tal entendimento teve espaço.

A deslegalização, de maneira simplória, não é nada mais que o fato de uma lei fazer referência expressa que determinado campo normativo será normatizado por regulamentos independentes. Nas palavras de Eduardo García de Enterría e TomásRamón Fernández (1995, apud BINENBJOM) 2008, p. 278):

Chamamos deslegalização a operação que efetua uma lei que, sem entrar no campo de regulação material de um certo tema, até então regulado por lei anterior, abre o referido tema para a posterior disponibilidade de regulamentação pela Administração. (GARCÍA DE ENTERRÍA $e$ FERNÁNDEZ, 1995, apud BINENBJOM 2008, p. 278).

Dessa forma, a lei não regula propriamente o tema, apenas refere qual o órgão que terá competência para normatizá-lo. Nesse sentido, Diogo de Figueiredo Moreira Neto (2003) assevera que a deslegalização constitui uma forma anômala de delegação legislativa:

A terceira técnica geral de delegação vêm a ser a deslegalização, oriunda do conceito do desenvolvido na doutrina francesa da délégation de matières, adotado na jurisprudência do Conselho de Estado em dezembro de 1907 (...) a qual, modificando postura tradicional, no sentido de que o titular de um determinado poder não tem dele disposição, mas, tão-somente, o exercício, passou a aceitar, como fundamento da delegação, a retirada, pelo próprio legislador, de certas matérias do domínio da lei (domaine de la loi), passandose ao domínio do regulamento (domaine de l'ordonnance). (MOREIRA NETO, 2003, p. 122)

Esposa, outrossim, tal posicionamento, Alexandre dos Santos Aragão (2005): 
Por este entendimento, com o qual concordamos, não há qualquer inconstitucionalidade na deslegalização, que não consistiria propriamente em uma transferência de poderes legislativos, mas apenas na adoção, pelo próprio legislador, de uma política legislativa pela qual transfere a uma outra sede normativa a regulação de determinada matéria $E$, com efeito, se este tem poder para revogar uma lei anterior por que não o teria para, simplesmente, rebaixar o seu grau hierárquico? Por que teria que, direta e imediatamente revogá-la, deixando um vazio normativo até que fosse expedido o regulamento, ao invés de, ao degradar a sua hierarquia, deixar a revogação para um momento posterior, ao critério da Administração Pública, que tem maiores condições de acompanhar e avaliar a cambiante e complexa realidade econômica e social?

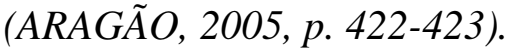

Nesse mesmo sentido, postula Henrique Ribeiro Cardoso (2006), sem posicionar-se:

Vislumbram os adeptos desta corrente estabelecer a Constituição Federal, no artigo que sedia a regulação em geral, art. 174 e nos que prevêem a criação das Agências Reguladoras - arts. 21, XI, e 177, § 2º, III- uma atribuição originária de competência normativa, dentro do esquadro de repartição de funções estabelecidas na Carta Política, em moldes semelhantes ao disposto nos arts. 62 e 68 da Constituição de 1988. (CARDOSO, 2006, p. 199).

O mesmo entendimento é compartilhado por Tércio Sampaio Ferraz Junior (2000), o qual deixa de citar expressamente o termo deslegalização, sem, no entanto, afastar-se da tese em tela:

Condicionada à previsão legal (legalidade no sentido de legitimação), a correspondente delegação (direta ao órgão) não se confunde nem com as delegações de fiel cumprimento nem com a lei delegada. Trata-se, como visto, de uma forma de delegação com base no princípio da eficiência e por este introduzida no ordenamento constitucional. Afinal, no caso de atividade reguladora, sem ela ficaria vazio o princípio, tanto no sentido de sua eficácia quanto no sentido de controle constitucional. (FERRAZ JÚNIOR, 2000, p. 154155).

Alexandre de Moraes (2002, p. 17-20) defende, de maneira um pouco mais prudente, que as agências reguladoras podem receber do poder legislativo delegações para regular certas matérias, cabendo aos legisladores estabelecer standards para atuação das referidas autoridades.

$\mathrm{Na}$ linha do que preconiza Gustavo Binenbojm (2008, p. 280-290), a aplicabilidade da deslegalização não merece guarida no ordenamento constitucional vigente no país. 
Argui o referido autor, que Carta Magna delineia as possibilidades de delegação legislativa de maneira expressa: no art. 62, as Medidas Provisórias e no art. 68, as Leis Delegadas ao Presidente da República. Já o art. 84, IV (após a emenda constitucional $n^{\circ}$ 32/2001), consagra a possibilidade de expedição de regulamentos autônomos pelo chefe do poder executivo. No entanto, tal possibilidade é restrita à “a) organização e funcionamento da administração pública federal (...) e b) extinção de funções ou cargos públicos, quando vagos". Dessa forma, os regulamentos autônomos só podem ser efetivados quando se estiver buscando a aplicação dos preceitos constitucionais, sendo que uma lei posterior que regule a mesma matéria tomará o seu lugar. Há uma espécie de preferência pela lei ${ }^{16}$.

Ademais, cumpre salientar que o art. 25 do Ato das Disposições Constitucionais Transitórias - ADCT preceitua:

Art. 25. Ficam revogados, a partir de cento e oitenta dias da promulgação da Constituição, sujeito este prazo a prorrogação por lei, todos os dispositivos legais que atribuam ou deleguem a órgão do Poder Executivo competência assinalada pela Constituição ao Congresso Nacional, especialmente no que tange a:

I - ação normativa

Cabe ainda referir as palavras de Gustavo Binenbojm (2008): “de acordo com o raciocínio até aqui desenvolvido, a deslegalização constituiria uma fraude ao processo legislativo contemplado na Constituição" (BINENBOJM, 2008, p. 283), o qual tem por escopo a defesa das garantias fundamentais do cidadão, não deixando margens a autoritarismos.

Nessa esteira, urge que seja feita uma citação do referido autor, em defesa do princípio da legalidade:

Rememore-se que o princípio da legalidade serve tanto à autonomia pública dos cidadãos (democracia) como a sua autonomia privada (liberdade). Por seu intermédio, os cidadãos podem tornar-se autores das suas próprias normas de direito (autonomia pública) e defender a sua vida particular de indevidas interferências (autonomia privada). Em uma palavra, por meio do império da lei, os cidadãos tornam-se senhores do seu destino coletivo (democracia) e individual (liberdade). Esta a dimensão substantiva do princípio da legalidade. (BINENBOJM, 2008, p. 287).

16 Para um estudo mais aprofundado da matéria, ver Gustavo Binenbojm: Uma Teoria do Direito Administrativo: Direitos Fundamentais, Democracia e Constitucionalização, Rio de Janeiro: Renovar, 2008. 


\subsection{Natureza de Regulamento}

Gustavo Binenbjom (2008 p. 284-290), como já exposto rechaça a tese da deslegalização. Ao fazer isso, defende que as normas expedidas pelas agências reguladoras devem ter caráter infralegal, igualando-se aos regulamentos editados pelo chefe do executivo, atuando, contudo, dentro do espaço delimitado pelas leis ordinárias.

Nesse sentido, afirma:

Como já longamente explicitado no Capítulo IV, supra, a competência normativa das entidades reguladoras exibe natureza regulamentar infralegal, semelhante àquela reconhecida ao chefe do poder executivo. (BINENBOJM, 2008, p. 286).

Igualmente, Marçal Justen Filho (2002, p. 540) afirma que "uma agência reguladora não pode fazer algo além ou diverso do que seria reconhecido ao Poder Executivo, em matéria de produção normativa."

O mesmo autor preceitua (2002, p. 518), outrossim: "afigura-se que a competência normativa abstrata das agências, no direito brasileiro, tem de ser enquadrada como manifestação de discricionariedade".

Cumpre salientar que esposa essa corrente Juarez de Freitas:

(...) os atos regulatórios devem ser infralegais, restando vedado ao administrador inovar como legislador. Assim, por exemplo, a resolução de uma agência reguladora pode inovar apenas como ato administrativo, porém nos exatos limites da lei. A infralegalidade reivindica uma sadia autocontenção. Não há, portanto, falar 'deslegalização' no campo regulatório, que pode até valer noutros contextos, mas não tem guarida em nosso complexo normativo". (FREITAS, 2004, p. 48).

Manoel Gonçalves Ferreira Filho (2002, p. 142), igualmente, defende tal posicionamento, asseverando que não há qualquer previsão constitucional para que leis possam delegar competência material para que um regulamento autônomo normatize determinado setor. Argumenta no mesmo sentido de Gustavo Binenbojm.

A jurisprudência pátria veio ao encontro dessa tese, referendando-a. Nesse sentido, o STF decidiu, em caráter liminar, no julgamento da ADI 1.668/DF, que a ANATEL estaria adstrita à Lei de licitações. Dessa forma, destaca-se da ementa:

(...) 3) deferir, em parte, o pedido de medida cautelar para: a) quanto aos incisos IV e X, do art. 19, sem redução de texto, dar-lhes interpretação conforme à Constituição Federal, com o objetivo de fixar exegese segundo a 
qual a competência da Agência Nacional de Telecomunicações para expedir normas subordina-se aos preceitos legais e regulamentares que regem outorga, prestação e fruição dos serviços de telecomunicações no regime público e no regime privado (....).

(STF, ADI 1668 MC, Relator(a): Min. Marco Aurélio, Tribunal Pleno, julgado em 20/08/1998, diponível em <www.stf.jus.br> acesso em 13/06/2009).

No mesmo sentido já decidiu o Superior Tribunal de Justiça:

PROCESSUAL - COMERCIALIZAÇÃO DE PRODUTOS NATURAIS ISENÇÃO DE REGISTRO NO MINISTÉRIO DA SAÚDE - PREVALÊNCIA DA LEI 6.360/76 SOBRE A RESOLUÇÃO RDC 23-ANVS/MS/99, DE HIERARQUIA INFERIOR -INSERÇÃO DOS PRODUTOS NO COMÉRCIO. Negar provimento ao recurso especial (STJ, REsp. 434.303/PR, Rel. Min. Eliana Calmon, julgado em 05/09/2002, disponível em 〈www.stj.jus.br> acesso em 13/06/2009).

Dessa forma, os tribunais superiores vêm entendendo que a tese da deslegalização não recebeu locus na ordem constitucional brasileira, tendo os regulamentos expedidos por agência reguladoras natureza infralegal.

\subsection{Natureza de Ato Normativo-Administrativo}

Maria Sylvia Zanella Di Pietro (2006, p. 457) defende a tese de que as normas emitidas pelas Agências Reguladoras devem estar em nível inferior inclusive dos regulamentos do chefe do Poder Executivo, via decreto. Essa tese submete as agências reguladoras ao império do executivo:

Mesmo as agências reguladoras das telecomunicações e do petróleo, previstas na Constituição como órgãos reguladores, ao baixar normas voltadas à 'regulação' dos setores que lhes são afetos, têm que observar a hierarquia das normas, inclusive a superioridade das normas regulamentares baixadas pelo Chefe do Poder Executivo, titular único da função. (DI PIETRO, 2003, p. 53).

Defende a autora que esse caráter não subordina as agências reguladoras aos arbítrios do poder executivo, tendo em vista a discricionariedade administrativa que é conferida aos administradores.

Tal tese não será mais aprofundada. Trata-se de um posicionamento praticamente isolado, sendo que a discussão principal insere-se acerca da hierarquia dos regulamentos em face das leis, discussão já elevada a limites nos itens anteriores.

Dessa forma, resta estabelecido que os regulamentos expedidos pelas agências reguladoras, à guisa do entendimento já manifestado pelo STF e pelo STJ, devem estar 
em um campo inferior ao legal. Com efeito, cumpre ainda nesse trabalho tecer algumas palavras no que concerne à inserção dos regulamentos autônomos no ordenamento, de maneira que prestigie a legitimação popular e o controle social.

\section{AS AGÊNCIAS REgUladoraS E O CONTROLE DEMOCRÁtiCO DE SEUS REGULAMENTOS}

O poder executivo central, Presidente da República e Ministros de Estado, estão respaldados pelo voto, o que lhes confere legitimação popular para tomar decisões. Nesse sentido, cabe a eles definirem as políticas públicas genérica que nortearão a administração pública.

Alexandre Santos de Aragão (2005, p. 05) opina no sentido de que a adstrição das agências reguladoras às políticas públicas estabelecidas pelo executivo não deve surpreender a ninguém. Para o referido autor, tal situação não compromete a autonomia e a existência de competências próprias das autoridades competentes. Assim, cabe às agências reguladoras a execução autônoma e técnico-burocrática das políticas ditadas pela administração central.

Para Gustavo Binenbojm (2008, p. 292), “a submissão dos órgãos reguladores às políticas públicas traçadas pela Administração Central é uma forma de controle pelo Poder Executivo que se encontra prevista nas próprias leis instituidoras das agências". De outro modo, cumpre salientar, como afirma o mesmo autor, que o art. 87, parágrafo único, inciso I, da Constituição confere aos ministros a tarefa de "exercer a orientação, coordenação e supervisão dos órgãos e entidades da administração federal".

Nesse contexto, não há nada de errado ou ilógico no fato de as agências reguladoras estarem submissas às políticas públicas exaradas pelo poder central. Há que se ter em vista que a soberania popular deu respaldo para que o presidente alcançasse o poder, o que torna imperioso que as políticas públicas por ele definidas sejam o norte de todo as atividades desenvolvidas no seio da administração. Trata-se de uma forma de coadunar a independência das autoridades autônomas com a vontade popular externada no voto,

Vale referir que, embora não exista previsão legal para recursos das decisões tomadas no âmbito das autoridades regulatórias, no entendimento do Parecer no 51/2006 da Advocacia Geral da União, os Ministros de Estado possuem poderes para rever 
decisões proferidas por agências reguladoras em duas hipóteses: (a) a agência tenha desbordado dos limites legais de suas competências; ou (b) a agência tenha usurpado competências de elaboração de políticas públicas setoriais de competência do Ministério (BINENBOJM, 2008, p. 276).

Destarte, tal parecer (embora consagre um recurso hierárquico impróprio sem previsão legal), é dotado, na intenção, de certa sabedoria, desde que sua interpretação seja extremamente restritiva às hipóteses elencadas. De fato, não é de mau tom que um Ministro possa rever atos das autoridades independentes que tenham usurpado limites de competência. No entanto, a utilização exacerbada (fora das hipóteses elencadas) desses recursos desvirtuaria os próprios propósitos das agências reguladoras.

Noutro passo, o controle social sobre as agências reguladoras ainda é algo extremamente incipiente no contexto brasileiro. Nesse sentido Gustavo Binenbojm (2008, p. 297-300) destaca dois tipos fundamentais de participação popular nas decisões tomadas pelas agências reguladoras: a consulta pública e as audiências públicas.

As audiências públicas constituem um meio eficaz de consulta popular, haja vista que é um espaço aberto no qual qualquer indivíduo pode expor sua posição acerca do tema em questão, o que pode acabar abalizando as decisões tomadas pela autoridade, procurando-se tomá-las da maneira mais adequada possível. No entanto, há que se ressalvar o fato de o comparecimento a essas audiências ser mais denso por parte dos interessados no tema em discussão. Dessa forma, é bem possível que empresas, com interesse econômico específico sejam mais escutadas que a sociedade em geral. As legislações atinentes à ANATEL e à ANP mencionam expressamente as audiências públicas.

Inobstante a falha acima apontada, tem-se nas audiências públicas, um meio realmente eficaz de aumento da participação popular nas decisões das autoridades reguladores e, por conseguinte, nas normas por elas expedidas, o que confere maior grau de legitimidade a tais normativas.

Noutro giro, a consulta pública "consiste no questionamento à opinião pública acerca de assuntos de interesse coletivo, ordinariamente, antes da elaboração das normas jurídicas" (BINENBOJM, 2008, p. 297). Assim, habitualmente, ela é feita de maneira individual e durante certo período de tempo. Dessa forma, o ato em discussão é publicado em veículo abrangente e os cidadãos manifestam-se como lhes convir. A falha apontada aqui é o fato de muitas pessoas nem tomarem conhecimento das 
consultas que, em muitas vezes, são realizadas nos sites, das agências sem ampla divulgação.

Com efeito, embora com falhas, os dois mecanismos acima expostos devem ser valorizados e aperfeiçoados, haja vista que aumentam o controle social sobre as autoridades independentes.

Desse modo, tem-se que a participação popular nas decisões das agências constitui um meio de o indivíduo proteger seus direitos fundamentais ${ }^{17}$. Nesse sentido manifestou-se Alexandre Santos de Aragão:

Com efeito, o principal mecanismo de legitimação democrática da Administração Pública é o da participação dos titulares de interesses individuais, coletivos e difusos através de audiências e consultas públicas prévias à edição dos atos normativos que possam afetar seus interesses. (ARAGÃO, 2005, p. 13).

\section{CONSIDERAÇÕES FINAIS}

Esse trabalho procurou demonstrar o quanto os regulamentos das agências reguladoras podem ser relevantes na conjuntura atual. Em um primeiro momento, discorreu-se sobre a necessidade de o Estado intervir na economia. Após, fez-se um apanhado histórico do surgimento dessa modalidade de autoridade reguladora independente no Brasil, comparando com o que ocorreu nos Estados Unidos.

Dessa forma, o Brasil implantou na década de 1990 uma reforma do Estado, com o intuito de transferir determinados setores para a iniciativa privada. Tal prática, sem fazer qualquer juízo de valor, gerou a necessidade de criação de entes reguladores independentes no país. Devido ao caráter técnico das normas a serem expedidas, bem como ao interesse da população em jogo, essas agências devem possuir uma autonomia reforçada com o escopo de não submeter suas decisões aos arbítrios dos interesses governamentais.

Com efeito, uma decisão de uma agência reguladora, como, $v . g$., a de subir uma tarifa de telefonia, não pode ser manipulada de acordo com interesses do governo, de forma que a autoridade possa se aproveitar do fato para obter lucros eleitorais (não permitir que a tarifa suba em época de eleições ou permitir seu incremento demasiado

${ }^{17}$ O Supremo Tribunal Federal já se manifestou no Mandado de Segurança 24.184-DF, rel. Min. Ellen Gracie proclamando a nulidade de ato do Instituto Nacional do Meio Ambiente e Recursos Naturais Renováveis - IBAMA que criou uma Unidade de Conservação sem prévia consulta pública, a qual é prevista em lei. 
em momentos de baixa densidade política). Assim, a independência das autoridades reguladoras é impositiva no contexto hodierno.

Destarte, a Administração Pública passa de um executivo unitário e hierarquizado, a um executivo policêntrico, no qual as decisões não estão submetidas somente à cúpula da pirâmide administrativa.

No entanto, impõe-se que certos limites sejam impostos à atuação das agências reguladoras para que não se afete a Democracia e os Direitos Fundamentais.

O primeiro limite é o de conferir natureza infralegal a seus regulamentos. Como já exposto alhures, a tese da deslegalização não mereceu guarida no ordenamento pátrio. Os regulamentos não podem estar no mesmo patamar das leis ordinárias, tendo em vista que aquelas são legitimadas pelo poder legislativo, o qual foi devidamente eleito e representa, de modo claro, a vontade da coletividade. Da mesma forma, é interessante que as normas em questão tenham congruência com as políticas públicas do governo, legitimado pelo voto da sociedade.

Noutro passo, o controle social sobre as agências reguladoras é algo, igualmente, impositivo. Seja através das consultas públicas, seja através das audiências públicas, ou ainda mediante outro meio eficaz de avaliação da vontade popular, as agências devem ouvir o que os membros da sociedade têm a dizer. Tais ações conferem um grau maior de legitimidade a qualquer ato normativo que venha a ser exarado pela autoridade independente.

Por derradeiro, cumpre salientar que as agências reguladoras devem cumprir seu papel na consolidação da Democracia e dos Direitos Fundamentais, atuando de maneira congruente com os propósitos do Estado de Direito, regulando setores específicos da economia e protegendo direitos individuais, coletivos e difusos.

\section{REFERÊNCIAS BIBLIOGRÁFICAS}

ARAGÃo, Alexandre Santos de. As Agências Reguladoras e a Evolução do Direito Administrativo Econômico. Rio de Janeiro: Forense, 2005.

ARAGÃO, Alexandre Santos de. A Legitimação Democrática das Agências Reguladoras. In: BINENBOJM, Gustavo (coord). Agências Reguladoras e Democracia. Rio de Janeiro: Renovar, 2005.

BARBOSA GOMES, Joaquim B. Agências Reguladoras: A "Metamorfose" do Estado e da Democracia (Uma Reflexão de Direito Constitucional Comparado). In: 
BINENBOJM, Gustavo (coord). Agências Reguladoras e Democracia. Rio de Janeiro: Renovar, 2005.

BARROSO, Luís Roberto. Agências Reguladoras: Constituição, Transformação do Estado e Legitimidade Democrática. In: BINENBOJM, Gustavo (coord). Agências Reguladoras e Democracia. Rio de Janeiro: Renovar, 2005.

BINENBOJM, Gustavo. Uma teoria do Direito Administrativo: Direitos Fundamentais, Democracia e Constitucionalização. Rio de Janeiro: Renovar, 2008.

BRASIL. Supremo Tribunal Federal. ADI 1949 MC, Relator(a): Min. SEPÚLVEDA PERTENCE, Tribunal Pleno, julgado em 18/11/1999, disponível em <www.stf.jus.br>, acesso em 13/06/2009.

BRASIL. SUPREMO TRIBUNAL FEDERAL. ADI 1668 MC, Relator(a): Min. Marco Aurélio, Tribunal Pleno, julgado em 20/08/1998, disponível em <www.stf.jus.br> acesso em 13/06/2009).

BRASIL. Superior Tribunal de Justiça. REsp. 434.303/PR, Rel. Mn. Eliana Calmon, julgado em 05/09/2002, disponível em <www.stj.jus.br> acesso em 13/06/2009.

CARDOSO, Henrique Ribeiro. O poder normativo das agências reguladoras, Rio de Janeiro: Lumen Juris, 2006.

DI PIETRO, Maria Sylvia Zanella. Limites da função reguladora das agências diante do princípio da legalidade. In: DI PIETRO, Maria Sylvia Zanella (coord). Direito Regulatório: temas polêmicos. São Paulo: Atlas, 2003.

DI PIETRO, Maria Sylvia Zanella. Direito Administrativo. 19 ed. São Paulo: Atlas, 2006.

FERRAZ JUNIOR, Tércio Sampaio. Agência Reguladora: legalidade e constitucionalidade. In: Revista Tributária de Finanças Públicas, $\mathrm{n}^{\mathbf{o}} 35$, ano 08, novembro-dezembro de 2000. São Paulo: Revista dos Tribunais, 2000.

FERREIRA FILHO, Manoel Gonçalves. Estudos, documentos debates: reforma do Estado, papel das agências reguladoras e fiscalização. São Paulo: FIESP/CIESP e Instituto Roberto Simonsen, 2000.

FREITAS, Juarez. O controle dos Atos Administrativos e os Princípios Fundamentais. $3^{\text {a }}$ Ed. São Paulo: Malheiros, 2004, p.48.

JUSTEN FILHO, Marçal. O Direito das Agências Reguladoras Independentes. São Paulo: Dialética, 2002.

MEDAUER, Odete. Direito Administrativo Moderno. $7^{a}$ Ed. São Paulo: Revista dos Tribunais, 2003.

MEIRELLES, Hely Lopes. Direito Administrativo Brasileiro. 26a Ed. São Paulo: Malheiros, 2001. 
MORAES, Alexandre de. Direito Constitucional. 22a Ed. São Paulo: Atlas, 2007.

MORAES, Alexandre. Agências Reguladoras. In: MORAES, Alexandre (org.). Agências Reguladoras. São Paulo: Atlas, 2002.

MOREIRA NETO, Diogo de Figueiredo. Direito Regulatório. Rio de Janeiro: Renovar, 2003,

NEVES, Marcelo. Entre Thêmis e Leviatã: uma relação difícil. São Paulo: Martins Fontes, 2008.

NUSDEO, Fábio. Curso de Economia: Introdução ao Direito Econômico. $4^{\mathrm{a}}$ Ed. São Paulo: Revista dos Tribunais, 2005.

PEREIRA NETO, Caio Mario da Silva; CORREA, Paulo. Delegações de Funções para Agências Reguladoras Independentes: Mudanças Propostas pelo Projeto de Lei 3 3.337/04. In: BINENBOJM, Gustavo (coord). Agências Reguladoras e Democracia. Rio de Janeiro: Renovar, 2005.

RAWLS, John. Uma Teoria da Justiça (A Theory of Justice). Trad. Jussara Simões e Álvaro de Vita. São Paulo: Martins Fontes, 2008.

SILVA, José Afonso da. Curso de Direito Constitucional Positivo. São Paulo: Malheiros, 2006. 